\title{
ELECTRONIC LEGISLATIVE INITIATIVE AS A TOOL TO IMPROVE CITIZENS' PUBLIC ACTIVITY IN CYBERSPACE: COMMON ISSUES IN THE BRICS COUNTRIES, EUROPE AND THE RUSSIAN FEDERATION
}

\author{
KSENIA IVANOVA, \\ Tyumen State University (Tyumen, Russia)
}

DOI: $10.21684 / 2412-2343-2018-6-1-102-126$

Around the world, parliaments, governments, civil society organizations and even individual parliamentarians are taking measures to make the legislative process more participatory. A key instrument of such measures is e-democracy. In the 1980s, a number of pilot projects on electronic voting and online discussions were introduced. However, only since 2000, with the active development of the Internet, has considerable interest in utilizing electronic initiatives to advance democracy emerge.

Today, researchers warn that despite all the talk about "e-democracy," the circle of actual decision makers is likely to remain as small as it has been heretofore.

In this article, the author analyzes the pros and cons of electronic initiatives in the BRICS countries, Europe and the Russian Federation, and provides practical information for improvement.

The author suggests that the next step needed to improve civil activity in filing legislative initiatives is the application of a regular mechanism to establish the possibility of organizing the process of civil legislative initiative nomination and the collection of signatures in electronic form, in particular via the Internet, with the possible use of crowd sourcing technologies.

Keywords: electronic resource; civil legislative initiative; e-democracy.

Recommended citation: Ksenia Ivanova, Electronic Legislative Initiative as a Tool to Improve Citizens' Public Activity in Cyberspace: Common Issues in the BRICS Countries, Europe and the Russian Federation, 6(1) BRICS Law Journal 102-126 (2019). 
Table of Contents

\section{Introduction}

\section{The Possibilities of Citizens' E-legislation in the BRICS Countries \\ 2. Citizens' Legislation Initiatives in the Laws of European Countries \\ 3. The European Citizens' Initiative (ECl) with Regard \\ to European Participative Democracy \\ 4. Possibilities of Electronic Civil Legislation Initiatives \\ in European Countries \\ 5. The Modern Possibilities of Citizens' Electronic Initiatives \\ in the Russian Federation \\ Conclusion}

\section{Introduction}

One of the necessary conditions for the development of a democratic civil society is the comprehensive realization of the legislative initiative that is created directly by the people. The civil legislative initiative is a form of direct implementation of a part of state power by the people. It is achieved through the introduction of a legislative proposal or the drafting of a proposed law, or repealing or amending previously adopted laws, with a view to the subsequent adoption of such a regulatory act by the legislative body of the appropriate level. Citizens prepare the draft act and collect the signatures, for the very fact that this particular project was considered by the authorized government body. In political terminology, the initiative is a process that enables citizens to bypass their state legislature by placing proposed statutes, and in some states, constitutional amendments, on the ballot.

The civil legislative initiative refers to the initial, primary forms of democracy and lawmaking, the expression by the people of their will, and it comes along with such forms of direct democracy as the referendum and elections. It is the right of a certain group of voters to propose a draft law, which is subject to mandatory review by the legislature.

Citizens' initiatives allow the electorate to vote on a political, constitutional or legislative measure proposed by a number of citizens, not by the government, the legislature or other political authority. To bring an issue to a vote, the proponents of the measure must gather enough signatures in support of it as the law requires. Citizens' initiatives may deal with new proposals, existing laws or constitutional measures, as determined by the particular jurisdiction. Depending on the authorizing law, the result of an initiative vote may be legally binding or advisory. Agenda initiatives are procedures by which citizens can place a particular issue on the agenda of a parliament or legislative assembly. As with citizens' initiatives, in order for the initiative to be 
brought forward to the legislature the law generally specifies a minimum number of signatures required. Unlike the procedure for citizens' initiatives, no popular vote takes place when an agenda initiative is brought forward.

For example, in the Russian Federation the official body, generally, can take any decision: to agree with the project, amend it or reject it. In this way, the civil legislative initiative differs both from a referendum, because decisions made via referendum have the force of law, and from the right to appeal to the authorities with proposals (petitions) that presuppose an answer, but do not require mandatory consideration at the legislative level.

The right of legislative initiative can be implemented in the form of a legislative proposal or a ready-made bill. Theoretically, the difference between these two forms follows from the literal sense of the two terms: the first means the idea, the concept of the future law; the second assumes the existence of a text with all of the attributes of a law (preamble, articles, paragraphs, precise formulations, etc.). A more facilitated form of implementation characterizes the legislative proposal (e.g., it can be made orally).

The term "full-scale initiative" is used for initiatives which are followed by a ballot and the term "agenda initiative" is used for initiatives which are dealt with by a representative body. Like referendums, citizens' initiatives are regarded as forms of direct democracy, for they allow citizens to be directly involved in the policy-making process. As already indicated, popular initiatives are often linked to a referendum, although this is not always the case.

Agenda initiatives seem to be more easily acceptable to those who tend to be skeptical about referendums and who trust the capacity of parliamentary institutions and procedures to bring about considered and enlightened decisions. It is also notable that, compared with initiatives leading to referendums, the interests of minority groups could be expected to be considered more in parliamentary procedures which involve deliberative processes, most importantly in committees. The institution of agenda initiative does not conflict with the idea of parliamentary sovereignty and it does not change the distribution of institutional power in representative democracies. In fact, agenda initiatives can often be seen as a compromise between the promoters and opponents of direct democracy, and for this reason they are perhaps a highly viable option for expanding the opportunities for citizen participation. Indeed, agenda initiative institutions are relatively widespread in Europe, and they are also used in some of those U.S. states which do not allow a full-scale initiative. ${ }^{2}$

Annette M. Fath-Lihic, The Instruments of Direct Democracy, International Institute for Democracy and Electoral Assistance, 21 December 2016 (Jan. 3, 2019), available at http://www.idea.int/news-media/ news/instruments-direct-democracy.

2 Georg Lutz, Switzerland: Citizens' Initiatives as a Measure to Control the Political Agenda in Citizens' Initiatives in Europe: Procedures and Consequences of Agenda-Setting by Citizens 17 (M. Setälä \& T. Schiller (eds.), London: Palgrave Macmillan, 2012). 
The Swiss institution of popular initiatives on constitutional amendments is a good example of a full-scale initiative, whereas, for example, the Spanish initiative institutions are a clear-cut case of agenda initiative practices. In some countries, such as Austria and Poland, only forms of agenda initiatives are available, whereas Latvia and Switzerland provide only a full-scale initiative. In other countries, both kinds of initiative institutions exist (for example Italy, Lithuania and Slovakia). ${ }^{3}$

The present analysis of the citizens' initiative mechanism includes a description of the current legal situation as well as the current possibility for citizens to exercise their legislation right via the Internet. Additionally, the article includes a review of the citizens' right to exercise their right to direct governance as practiced in previous and current parliamentary terms.

\section{The Possibilities of Citizens' E-legislation in the BRICS Countries}

Citizens can make a difference. In a parliamentary democracy, the people place their trust in representatives to formulate laws and oversee the executive branch. A major reason for this system is the difficulty of practicing direct democracy in a contemporary mass society. The individual has too weak a voice to have an impact. The level of mistrust in parliaments has increased in recent decades. The most frequent reasons for this vary from the limitations of traditional political representation, which create a democratic deficit, to the lack of the capacity to deal with complex social problems in lawmaking, but additionally corruption and the greater influence of powerful interest groups and corporations in the decisionmaking process. However, current information and communication technology (ICT) can act as steroids, enabling us to pump up individual voices, and foster a greater and more direct interaction between society and parliaments.

According to the National Portal of India,

India is the largest democracy in the world and citizens here are highly enthusiastic to be a part of Governance. ${ }^{4}$

The Honorable Prime Minister Shri Narendra Modi believes that,

Success of democracy is impossible without participation of the people.

3 Maria Marczewska-Rytko, Popular Initiative and Referendum in Switzerland (2000-2010), 9 Studies in Politics and Society 284 (2012).

4 Citizen Participation Towards Good Governance, National Portal of India (2014) (Jan. 3, 2019), available at https://www.india.gov.in/spotlight/mygov-citizen-participation-towards-good-governance. 
For that reason he initiated the creation of the online platform MyGov to empower the citizens of India to contribute towards Surajya ("good governance"). MyGov is an innovative platform launched on 26 July 2014 to ensure citizens' engagement in decision making by the government so that the ultimate goal of "good governance" for building India is achieved. This initiative is an opportunity for citizens and wellwishers from across the world to share their views on key issues directly with the Prime Minister of India.

The interesting point in such cooperation between the Indian government and its citizens is that the MyGov platform encourages the participation not only of the citizens of India but also of people abroad. There are multiple theme-based discussions on MyGov where people from a wide range of backgrounds can share their thoughts and ideas. Furthermore, any idea shared by a contributor will also be addressed in these discussion forums, allowing constructive feedback and interaction among participants.

MyGov aims to establish a link between government and citizens towards meeting the goal of good governance in the country. For those who wish to go beyond discussions and contribute on the ground, MyGov offers several avenues to do so. Citizens can volunteer to engage in various tasks, and submit their entries. The tasks will then be reviewed by other volunteer members as well as experts. Once approved, the tasks can be shared by those who complete the task with other members on MyGov. Every approved task earns credit points for completing the task. The website is hosted and managed by the National Informatics Centre (NIC). The registration process is very simple and quick on MyGov. A person needs only to fill in a simple sign-up form with personal details such as name, e-mail address, a 10-digit mobile phone number and a password.

As of the first week of September 2014, within forty-five days of its launch, 215,000 users were enrolled on MyGov and more than 28,000 users had submitted their ideas on a variety of issues. ${ }^{6}$ The platform attracted many users who were not previously engaged in other social media such as Facebook and Twitter. Within fifty days of its activation, more than 23,000 entries were received for seven different government ministries in addition to the Prime Minister's Office through the Creative Corner section of MyGov alone. The Creative Corner is aimed at receiving creative input such as logo creation and wallpaper designs from the public. Users may upload and vote on proposals on the relevant topics. Though the final results are not based on the votes, the votes are considered during the selection process by the selection committee. Thousands of contributions have been received to date.

What also distinguishes the Indian model of citizens' e-participation is that groups and creative corners are an important part of MyGov. The platform is divided into

\footnotetext{
MyGov (Jan. 3, 2019), available at https://www.mygov.in/.
}

6 Now, a CEO to Manage Govt's Digital Outreach, Business Standard, 13 September 2014 (Jan. 3, 2019), available at https://www.business-standard.com/search.php?q=search.php. 
a number of groups, namely Clean Ganga, Green India, Job Creation, Girl Child Education, Skill Development, Digital India and Swachh Bharat (Clean India). Each group consists of online and on-the-ground tasks that can be taken up by the contributors. The objective of each group is to bring about a qualitative change in that particular sphere through people's participation.

As is emphasized on the National Portal of India, MyGov is a small step towards the larger mission of becoming a one-stop center for citizen engagement in good governance. Over time the number of groups, tasks and discussions will increase. The portal will also be used as a comprehensive knowledge repository, providing important insights from the sharpest and brightest minds across India.

In Brazil, the e-Democracia Project was launched in 2009 by the Brazilian House of Representatives. ${ }^{7}$ e-Democracia aims at engaging citizens in the lawmaking process to achieve tangible legislative results. Relying on the use of social media, combined with offline legislative events (e.g. committee hearings, conferences), the initiative is intended to reach a broad segment of the public, including citizens, parliamentarians, civil servants, researchers, nongovernmental organizations and interest groups.

The program is a type of crowdsourcing for legislative purposes. In particular, the e-Democracia website attracts and draws together the diffuse participation of individual citizens and minority groups. The main goal is to permit easier access to the decision-making process by citizens who are not associated with strong interest groups or corporations that usually lobby for access to the centers of power in Brasilia where the national government is located.

Brazil's e-Democracia platform is driven by the belief that the lawmaking process can benefit from the convergence of political representation and citizen participation in a virtuous cycle where one model strengthens the other. People in contemporary societies have very diverse interests, experiences, expertise and values. A great challenge in making social participation feasible is to discover how to take advantage of such diversity and incorporate it into the policy-making system. The engine behind e-Democracia is a "multiple participatory mechanism," a kind of electronic, permeable sponge that enables people to share their professional experience and expertise, express their personal and collective interests and values, and foster creative ideas in different forms and intensity, in all phases of the policymaking cycle. That participation may consider any contribution that citizens want to deliver, or are technically able to present. Some people will be interested in merely discussing ideas (solutions) in public forums, whereas others can be engaged in drafting ideas, simply by uploading useful information to describe the problem, or presenting arguments to support their ideas. One can even help to rank better ideas.

e-Democracia (Jan. 3, 2019), available at www.edemocracia.gov.br. 
Besides active participants, there will be many other citizens who are satisfied with simply monitoring the legislative discussion.

But the program faces a major hurdle in a huge country with a great digital divide: How do we engage offline Brazilians in the lawmaking process? The actual participation by an Amazon forest native highlights a possible path with which to create direct linkage between out-of-power communities and the legislature. This is explored further below, as it illustrates wonderfully that more inclusive participation to support digital participatory experiments expressed on government websites depends on many issues. ${ }^{8}$

The backbone of the initiative is its website (www.edemocracia.gov.br), which provides multiple participatory mechanisms with which citizens can: ${ }^{9}$

- share information about a problem that needs to be addressed by a law;

- identify and discuss possible solutions to the problem;

- draft the bill itself.

Since June 2009, e-Democracia has acquired five virtual thematic legislative communities (VLC), several forums, more than 100 topics, 700 contributions and 4,000 registered participants. The most successful experiments so far have been a housing policy and the youth statute virtual communities. As a result of the latter, ideas and suggestions delivered by young people throughout Brazil have been taken seriously by (some) policy makers and, in fact, reflected in the draft of the bill, not yet passed. ${ }^{10}$

One important issue that normally causes digital participation to fail is the lack of connection between people's contributions and how laws are actually drafted. Writing legal text involves great technical complexity. e-Democracia has minimized this problem by engaging the assistance of legislative consultants, who serve, essentially, as "technical translators" during the entire participatory process.

Participants in the youth statute discussion have posted comments and discussed several ideas during recent months. Legislative consultants summarized this participatory content and presented it to the lawmaker in charge of drafting the bill. After approval, the legislative consultants transformed the lawmaker's suggestions into legal text. Then, the lawmaker personally submitted it to the Youth Affairs Committee.

Here are some examples of how virtual contributions are reflected in real modifications of the youth policy bill draft (still under discussion):

8 Felipe de Paula, Does Brazil Have a Legislative Policy?, 4(3) The Theory and Practice of Legislation 329 (2016).

9 Cristiano Faria, Can People Help Legislators Make Better Laws?, Personal Democracy Media, 29 April 2010 (Jan. 3, 2019), available at http://techpresident.com/user-blog/can-people-help-legislatorsmake-better-laws-brazil-shows-how.

10 Cristiano Ferri S. Faria, Collaborative Online Lawmaking: Brazil's e-Democracia, Participedia, 21 May 2013 (Jan. 3, 2019), available at https://participedia.net/en/cases/collaborative-online-lawmakingbrazils-e-democracia. 
1) Participants' contribution - Participants wanted greater investment in internships and other professional programs for undergraduates, as well as greater flexibility in working conditions for students.

Draft bill:

Article 19. The action of the State to make effective the rights of youngsters to professionalization, labor and income includes the following measures:

III - an offer of special conditions of labor by matching the professional and educational schedule;

$\mathrm{VI}$ - the application of instruments of legal accountability for relevant organizations;

VII - the creation of special credit for working students;

IX - the introduction of apprenticeships in public administration.

2) Participants' contribution - Participants have cried out for greater empowerment of the local youth councils, bodies composed of youth representatives, politicians and experts.

Draft bill:

Article 46. The youth councils are permanent and autonomous bodies committed to formulating policies for the youth and guaranteeing effective implementation of the rights of the youth.

Article 47. The youth council duties are:

I - informing the General Attorney of any criminal infraction committed against youngsters;

IV - requesting information about matters of youth policy from public authorities;

$\mathrm{V}$ - advising the government on the formulation of youth policy;

(and other measures).

Since the launching of e-Democracia in 2009, its team has invested in several strategies to promote the website and engage a broader group of participants. First, articles about the e-Democracia initiative were published in the national electronic newspapers. Its website is accessible and open to anyone who completes a simple registration process. There is also a link to the web page on the House of Representative's website.

Second, the e-Democracia team sent out invitations to thematic blogs and social networking websites to engage people (e.g. environmentalists and youngsters) who are interested in those specific subjects. Third, the e-Democracia team posts daily messages to the e-Democracia's accounts at Twitter and Orkut (which is more popular than Facebook in Brazil). 
In China, the people's congress system is the fundamental system to facilitate political participation. Qiao Shi (1997) proposed a hierarchical structure for the people's congress in China: the National People's Congress (NPC) at the central level, the provincial people's congress and people's congress for municipalities, the people's congress in cities and counties. However, the existing system can hardly meet the citizens' needs to participate in the policy-making process.

Since civil organizations have emerged in the fields of education, public health and poverty reduction to meet the demand for public services that governments may not fully cover, they can serve as a platform where citizens are likely to assembly for participation purposes. However, since China initiated the Government Online Project in 1999 the number of websites with gov.cn registered as their domain reached 52,115 in 2014 and almost all governments at the county level and above have their own web portals (CNNIC, 2014). This growing trend of e-governance has propelled governments to be more open and transparent with data and information, making them more readily available to citizens. As a result, every ordinary citizen is now able to express his views freely on these online platforms, and policy makers can also turn to all of these different channels and platforms to gather feedback from citizens, guide public discourse and fine-tune policies.

In the initial phase of e-participation, some government officials often take on a hostile attitude towards electronic participation and regard "netizens" participation as harboring evil intentions. They think the network is not representative of public opinion, and some government leaders even see e-participation as a contributor to social instability. Hence, some government officials turned to deleting online posts, shutting down sites and tracking down those who are seen as causing social instability on the Internet. However, these strategies did not achieve good results. A few years later, some senior officials came to realize the importance of online opinions." In January 2007, the CPC Central organization held a thematic learning session about the development of network technology in the world and the construction and management of network culture in China. At the meeting, President Hu Jintao suggested that government officials at all levels should focus on mastering Internet knowledge so as to hone their leadership and strive to create a new norm for China's Internet culture.

With the deepening of e-government, some interactive platforms between government and the public began to emerge on government websites at all levels, such as the online leader mailbox, online interviews and the online consultation column. It is currently estimated that more than 90 percent of Chinese government websites have opened up the leader's mailbox to facilitate communication between the government and citizens. The names of the leader mailboxes may vary on different government websites (the mayor-mail, governor-mail), but their functions are

11 Liu Hui, Research on Citizens' E-participation in the Policy Making Process of China, a thesis submitted for the degree of master of social sciences, Department of Political Science, National University of Singapore (2014) (Jan. 3, 2019), available at https://scholarbank.nus.edu.sg/bitstream/10635/119282/1/ Master\%20Thesis\%20LIU\%2OHUI\%20A0095624.pdf. 
analogous. For example, the Shanghai Government website provides the resumes, photos and responsibilities of the party secretary and the mayor to guide citizens in writing e-letters. The online consultation channel is put in place with the intention to seek public opinions and suggestions on new or existing laws and policies. Citizens can express their views through a link provided by the website or through e-mail.

In South Africa, the current situation differs because the country has just started the process of e-governing. Taking into account the importance of public participation in the law-making process, the Parliamentary Support Programme (PSP) commissioned the Political Information Service of the Institute for Democracy in South Africa (IDASA) to undertake a research study of public participation in the legislative and policy-making process in South Africa.

The aim of the PSP is to promote good governance and democratization in South African legislatures at the national and provincial levels and to assist them in the performance of their responsibilities. These include legislation, policy formulation, executive oversight, constituency work, and public education and outreach. The PSP focuses on the following areas:

- Assisting legislatures with structural support and services;

- Promoting knowledge and legislative skills;

- Facilitating the participation of women;

- Funding and supporting improvements in institutional arrangements;

- Improving representation and responsiveness in the legislatures;

- Enhancing communication and cooperation between legislatures.

Public participation is central to any democracy and needs to go beyond voting at the national, provincial or local level. A dynamic process of engagement should be facilitated to allow the electorate to participate in processes that may affect their lives.

According to the Constitution of South Africa,

Everyone has the right, peacefully and unarmed, to assemble, to demonstrate, to picket and to present petitions.

However, there are certain procedures that individuals and/or groups have to follow when petitioning Parliament. The presentation of petitions is governed by the rules of Parliament. The National Assembly requires that a petition be formally presented by a Member of Parliament (MP) for consideration. Therefore the petition must be supported by an MP. A person is entitled to approach any MP by contacting them or by visiting the Constituency Office closest to him to seek their assistance with presenting a petition on his behalf. ${ }^{12}$

12 Petitions, Parliament of the Republic of South Africa (Jan. 3, 2019), available at https://www.parliament. gov.za/petitions. 
The young South African democracy is engaging in the process of public participation. By strengthening and building on the structures and practices that already exist, they can look forward to greater participation - and hence more effective governance - in the future. ${ }^{13}$

Summing up, the most developed platforms of citizens'e-participation legislation processes are in India and Brazil; and in India there is also the possibility to contact government ministers. In China, people can participate by submitting their comments via special online platforms. In South Africa, citizens' e-participation legislation is only an aim of the government. However, this country has the strong intention to develop electronic democracy.

\section{Citizens' Legislation Initiatives in the Laws of European Countries}

In most foreign countries, the lawmaking initiative of citizens is enshrined in the constitution of the state and is a form of expression of democracy. The concept and the mechanism for implementing the lawmaking initiative of citizens in foreign states were formed much earlier than in Russia, which explains its wider application.

Constitutions, providing the possibility of a people's legislative initiative, establish that in order to introduce a draft law, it is necessary to collect a certain number of voters' signatures whose authenticity should be verified and certified by a notary or local government official (usually this number corresponds to the number of signatures for the referendum initiative).

The legislative acts of a number of countries stipulate that the voters carrying out the people's legislative initiative should represent different parts of the country in a certain proportion. This is done in order to raise the issue to a national, rather than a local level. For example, in Brazil voters initiators are required to submit at least five states (out of 26); in Romania, at least one-quarter of the country's counties. Often there is a time limit for the collection of signatures: it usually is no longer than six months.

The civil legislative initiative, as well as the referendum, is usually not allowed on issues of taxation, amnesty, the budget process, international issues and issues of constitutional reform.

In Switzerland, the people's legislative initiative for partial revision of the constitution must come from 100,000 voters (para. 2 of Art. 139 of the Constitution of 1999). ${ }^{14}$

13 Hoosain Kagee, Acting National Director Parliamentary Support Programme, A People's Government, the People's Voice (June 2001) (Jan. 3, 2019), available at https://www.parliament.gov.za/peoplesgovernment-peoples-voice.

14 Союзная конституция Швейцарской Конфедерации от 18 апреля 1999 г. [Union Constitution of the Swiss Confederation of 18 April 1999] (Jan. 3, 2019), available at http://www.concourt.am/armenian/ legal_resources/world_constitutions/constit/swiss/swiss--r.htm. 
From the beginning of the 1990s, civil or national legislative initiatives as an institution were consolidated everywhere at the communal and land (Länder) levels. Citizens of the Federal Republic of Germany are increasingly using this tool, which presents the opportunity to directly address pressing political issues. In 19931994, five eastern lands included civil legislative initiatives and plebiscites in their new communal statutes, and by 1997 "direct democracy" had been implemented everywhere. Six of the eleven states of the former Federal Republic (the "old" Bundesländer) - Bavaria, Berlin, Bremen, Hesse, Nordrhein-Westfalen and RheinlandPfalz - incorporated both initiative and referendum into their new constitutions immediately after 1945. Baden-Württemberg and the Saarland followed suit in the 1970s. After 1990, the peaceful revolution in the former GDR unleashed a wave of reforms which meant that by 1994, all sixteen "old" and "new" federal states had introduced elements of direct legislation. ${ }^{15}$

There is a clear trend in Germany towards more direct democracy. However, the road towards a workable popular right to direct participation in decision-making is still long and arduous. The then ruling SPD/Green coalition presented a bill on citizens' initiative and referendum to the Bundestag in the summer of 2002. However, the proposal did not obtain the required supermajority of two-thirds of votes in the parliament. The federal government elected in 1998 - a coalition of the SPD, the citizens' rights party Bündnis 90 and the Greens - had promised to introduce a national right to citizen participation in legislation. Three of the five parties represented in the Bundestag supported this intention, but without the support of the CDU it could not obtain the two-thirds majority required in the Bundestag for constitutional change. There is still a chance that the initiative element of I\&R the right to force parliament to debate a topic chosen by the people - might be introduced. All the parties in the Bundestag promised that there would be a new attempt after the national elections in the autumn of 2002. This was hoped to usher in the first stage of a gradual introduction of direct democracy at the national level.

Reform attempts and successes continue today. For example, individual federal lands have reduced the threshold for consideration of the people's legislative initiative from 20 percent to 10 percent of voters. ${ }^{16}$

The United States uses an institution similar to the people's legislative initiative, the so-called petition referendum: a referendum held at the request of a certain number of voters who have signed a petition for acceptance, cancellation or amendment of the relevant law. In the United States, such a referendum is practiced in a significant number of states. The number of signatures on the petition may be low or very significant: from 2\% in Massachusetts, 3\% in Maryland, 5\% in Arizona,

15 Ralph Kampwirth, Direct Democracy in Germany, Direct Democracy Conference (2004) (Jan. 3, 2019), available at http://www.iniref.org/germany.html.

16 Id. 
California, Kentucky, Colorado and Michigan to $15 \%-20 \%$ in individual states. In a petition referendum, two institutions of direct democracy are combined: a people's legislative initiative and a referendum. ${ }^{17}$

Today in the United States there is a legislative initiative to incorporate into the national law the possibility for citizens to participate in legislative initiatives at the federal level. The National Citizens Initiative for Democracy (NCID) is a fundamental, one-time legislative proposal that allows citizens, independent of their representatives in government, to propose and vote on laws and amendments. NCID consists of a constitutional amendment and a federal statute. ${ }^{18}$

However, not in all developed European countries are citizens entitled to legislative initiative. For example, the traditional legislative initiative in the United Kingdom belongs only to Members of Parliament. Any legislative proposal should be put in the form of a bill, and the bill submitted to Parliament must necessarily be correctly drawn up. Individuals or organizations can introduce "private" bills only indirectly: during a petition to Parliament in the proper form, then they have to present their point of view at a meeting of the profile committee considering the bill.

In France, the population is given the right to a lawmaking initiative only at the local level. At the same time, in France people have the right to file petitions to the assembles, including the General Assembly. The right of citizens to file petitions has long been known in the French legal tradition, separately allocated is the right to address them to the parliament. In the Constitutions of 1791 and 1793 this right was listed among the basic rights of citizens. However, generally, citizens' appeals to parliament have limited consequences. Basically, the request is forwarded to the relevant authorities, but this right can also be regarded as a warning to parliament and even as a document that is a material expression of civil liberties. ${ }^{19}$ At present, this approach has again found its supporters at the European level, after the signing of the Maastricht Treaty of 1992.

According to Article 72-1 of the Constitution of the French Republic,

The conditions in which voters in each territorial community may use their right of petition to ask for a matter within the powers of the community to be entered on the agenda of its Deliberative Assembly shall be determined by statute. ${ }^{20}$

17 Politics in the American States: A Comparative Analysis (V.H. Gray et al. (eds.), $9^{\text {th }}$ ed., Washington, D.C.: CQ Press, 2008).

18 National Citizens Initiative for Democracy (Jan. 3, 2019), available at http://www.ncid.us/national initiative.

19 Stéphanie Renard-Biancotto, Le droit de pétition sous la cinquième République, 1 Revue de la recherche juridique, droit prospectif 223 (2000).

20 Constitution of 4 October 1958, French National Assembly (Jan. 3, 2019), available at http:// www2.assemblee-nationale.fr/langues/welcome-to-the-english-website-of-the-french-nationalassembly\#Title11a. 
However, the purpose of such an initiative is very limited, since it can only refer to a request at a meeting to discuss the issue and only if it is within the jurisdiction of the assembly. Initially, the draft law provided a genuine right to mandatory inclusion of appeals in the agenda, but senators reduced this right to a simple opportunity. They feared that including such a right would give the most active minorities too much power. Now this right seems more symbolic than real. To overcome this drawback, the mayor of Paris decided to grant such a right to the city residents. However, this initiative failed, because the question arose as to the legality of such actions by the mayor. The courts ruled that petitions in any case should be considered in a specially created committee, only to be able to give an advisory opinion on the possibility of including a petition on the agenda of the Council of Paris.

\section{The European Citizens' Initiative (ECI) with Regard to European Participative Democracy}

According to the Treaty of Lisbon, ${ }^{21} 1$ million EU citizens, residing in a significant number of Member States, may invite the European Commission to introduce a proposal of EU legislation in a certain area. This is aimed at increasing the involvement of European citizens in the making of EU policies. This would also enlarge the wide range of citizens' rights, adding to the right to elect MPs to the European Parliament (and to be elected oneself), to approach the European Ombudsman and to address requests to EU institutions.

To implement this provision of the treaty, the European Commission, after an extensive public consultation process, presented the draft Regulation on the Citizens' Initiative on 31 March 2010.

Following debates in the framework of the Council of the European Union and of the European Parliament, and negotiations between the two institutions, the draft regulation was adopted, according to the ordinary co-decision procedure, by the European Parliament and the Council in December 2010 and February 2011 respectively. The Regulation on the Citizens' Initiative came into force on 1 April 2011.22

A European citizens' initiative is an invitation to the European Commission to propose legislation on matters where the EU has competence to legislate. A citizens' initiative has to be backed by at least 1 million EU citizens, coming from at least seven out of the twenty-eight Member States. A minimum number of signatories is required in each of those seven Member States. A citizens' initiative is possible in

21 Treaty of Lisbon amending the Treaty on European Union and the Treaty establishing the European Community, signed at Lisbon, 13 December 2007 (Jan. 3, 2019), available at http://eur-lex.europa. eu/legal-content/en/TXT/?uri=CELEX\%3A12007L\%2FTXT.

22 Regulation (EU) No. 211/2011 of the European Parliament and of the Council of 16 February 2011 on the Citizens' Initiative (Jan. 3, 2019), available at http://eur-lex.europa.eu/legal-content/EN/TXT/ PDF/?uri=CELEX:02011R0211-20131008\&from=EN. 
any field where the Commission has the power to propose legislation, for example environment, agriculture, transport or public health. ${ }^{23}$

In order to launch a citizens' initiative, citizens must form a "citizens" committee' composed of at least seven EU citizens being resident in at least seven different Member States.

The members of the citizens' committee must be EU citizens old enough to vote in the European Parliament elections (18 years old, except in Austria, where the voting age is 16). Citizens' initiatives cannot be run by organizations. However, organizations can promote or support initiatives provided that they do so with full transparency. The citizens' committee must register its initiative online (European Citizens' Initiative, Official Register, http://ec.europa.eu/citizens-initiative/public/ basic-facts) before starting to collect statements of support from citizens. Once the registration is confirmed, organizers have one year to collect signatures.

When a citizens' initiative gets 1 million signatures, the Commission will carefully examine the initiative. Within three months after receiving the initiative Commission representatives will meet the organizers so they can explain in detail the issues raised in their initiative. The organizers will have the opportunity to present their initiative at a public hearing in the European Parliament. The Commission will adopt a formal response spelling out what action it will propose in response to the citizens' initiative, if any, and the reasons for doing so or not doing so.

The response, which will take the form of a communication, will be formally adopted by the College of Commissioners and published in all official EU languages. The Commission is not obliged to propose legislation as a result of an initiative. If the Commission decides to put forward a legislative proposal, the normal legislative procedure kicks off: the Commission proposal is submitted to the legislator (generally the European Parliament and the Council or in some cases only the Council) and, if adopted, it becomes law. ${ }^{24}$

One of the major problems early on relates to the difficulty that organizers have faced in setting up an online collection system on a secure data server (necessitated by the strict data protection and privacy requirements for $\mathrm{ECls}$ ), which has meant, as noted, that only eight $\mathrm{ECls}$ have begun (just recently) to collect online signatures. $\mathrm{ECI}$ organizers are left to invest their own energy and funds to find a host platform, notify data protection authorities, install the software, and prepare and submit risk and business management documents for certification of the online collection system. ${ }^{25}$

${ }^{23}$ The European Citizens' Initiative: Official Register (Jan. 3, 2019), available at http://ec.europa.eu/ citizens-initiative/public/basic-facts.

24 Regulation (EU) No. 211/2011, supra note 22.

25 Marcel Sangsari, The European Citizens' Initiative: An Early Assessment of the European Union's New Participatory Democracy Instrument, Canada-Europe Transatlantic Dialogue: Seeking Transnational Solutions to $21^{\text {st }}$ Century Problems, Policy Paper (January 2013) (Jan. 3, 2019), available at https:// carleton.ca/canadaeurope/wp-content/uploads/CETD_Sangsari_ECI_Policy-Paper.pdf. 
These actions are costly and not intuitive for citizens without the necessary technical and legal expertise. The European Citizen Action Service (ECAS), which has investigated the possibility of establishing an online collection system on a secure server in Brussels, estimates the cost of setting up one's own secure online system as falling within the range of $€ 20,000$ to $€ 30,000$, an amount beyond the means of most organizers.

While they have the option of using the Commission's free open-source software for signature collection, organizers recommend that the software should be made more user-friendly. In a recent article, Carsten Berg - Director of the $\mathrm{ECl}$ Campaign for a Citizen-Friendly ECI - provided suggestions for making the software more user-friendly for normal citizens and users, including the simple measure of giving signatories the option to check a box if they wish to stay in contact with the ECI organizers to receive updates and to build longer-term networks. Without such a simple feature, $\mathrm{ECl}$ organizers are limited in their ability to communicate with supporters of an initiative. ${ }^{26}$

To address these early difficulties and the complaints by $\mathrm{ECl}$ organizers and CSOs, the Commission offered, in an exceptional measure, to temporarily install the organizers' online collection system on a platform in the Commission's Datacentre in Luxembourg free of charge and to support organizers in their certification of the system with Luxembourgish authorities. The Commission also extended the period of collection for ECls registered before 1 November 2012 until 1 November 2013 (ECls registered after 1 November 2012 have the normal one-year period for signature collection from the date of registration). A fully staffed ECI help center as well as the provision of an improved online collection system, and a permanent host datacenter, would better facilitate the ability of citizens to make use of their new right. Indeed, one registered $\mathrm{ECl}$ is calling for the $\mathrm{EU}$ to establish a central online collection platform for ECls, a low barrier tool which works instantly and without the need for technical expertise. ${ }^{27}$

Although it sounds relatively simple to achieve the threshold of 1 million signatures, in fact this is a complex and challenging task, which involves collecting an average of 2,740 signatures a day. To reach the threshold, a successful campaign requires coordinated efforts over an extended period of time before and after the one year allowed to collect signatures.

Fortunately, the digital age and communications technologies are making it possible for individuals to connect across borders in an efficient manner, enabling citizens to

26 Chris Delaney, Amend the Recall and Initiative Law, The Globe and Mail, 12 August 2010 (Jan. 3, 2019), available at https://www.theglobeandmail.com/news/british-columbia/amend-the-recall-andinitiative-law/article1376908/.

27 Carsten Berg, Online Collection System Needs to Be Urgently Up-graded, The ECI Campaign, 28 October 2012 (Jan. 3, 2019), available at http://www.citizens-initiative.eu/online-collection-system-needs-tobe-urgently-up-graded/. 
easily network, and to do so with limited structures and budgets. While not a panacea, social media can be used as a cost-effective way to promote and provide updates on ECls. Media coverage now reaches beyond borders instantaneously. Online forums, such as initiative.eu, can provide an online space to federate would-be organizers of ECls sharing similar interests and to foster discussion. Funds can be collected by organizers in one country and rapidly transferred to another country where they are needed. Should a topic resonate well enough with the public, resources could in fact materialize ad hoc through crowd-sourced funding. ${ }^{28}$ In short, the capability for mass transnational collaboration facilitated by information communications technologies is within reach for $\mathrm{EU}$ citizens wishing to make use of $\mathrm{ECl}$.

\section{Possibilities of Electronic Civil Legislation Initiatives in European Countries}

Estonia is considered a pioneer in e-democracy: in 2001 the project "Today I Decide" (TID) was created. The idea was to create a portal that allowed citizens to share their suggestions on improving public administration and the legislative system, as well as to discuss new initiatives related to different spheres of social life. According to the initiative's developers, the principal objective was to increase voters' participation in shaping public policy and eliminate the barriers between society and the state.

This tool has proven to be a success, with over 7,010 registered users proposing and discussing 1,187 new initiatives. It has helped citizens' participation by allowing them to launch new ideas and to discuss them in an open forum, while guaranteeing them a concise answer from the decision-making level. Years of experience with this tool have made it clear that it can be a meaningful instrument for all governments and public bodies throughout the European Union. ${ }^{29}$

The present project TID+ is all about disseminating the tool and the lessons learned from it to interested parties in the EU. It re-evaluates and ameliorates the present solution, makes accessible comprehensive documentation on how it can be used optimally, and makes a software solution available free of charge for noncommercial use to all interested actors as a tool to increase citizens' participation. In this light, the main objectives of the project are:

1) to develop and disseminate an online tool, based on open source solutions, that allows for citizens' initiative and participation in proposing and discussing regulation; this tool should be easy to use by citizens, and should be easily adaptable by interested governments and institutions;

28 European Citizen Action Service, "European Citizens' Initiatives - A first assessment," Background Discussion Document No. 1 for the Conference "Building the EU Citizen Pillar," 5 November 2012, Brussels, Belgium (Jan. 3, 2019), available at http://www.ecas-citizens.eu/content/view/468/.

29 The TID+ Project (Jan. 3, 2019), available at http://tidplus.net/project/. 
2) to develop and disseminate the necessary documentation and guidelines that allow a productive and effective use of the tool in proposing and discussing regulation; this documentation should include past experiences, information on traps and pitfalls that could render the tool ineffective, and pointers on how best to use the outcomes of citizens' initiatives and participation.

A widely known initiative is the UK's e-petition. Following its launch by the government in 2011, any citizen or UK resident can create an e-petition to support a cause or ask for a change in policy or legislation, as well as sign other people's petitions. Each petition is open for up to one year, after which it will be considered for debate in the House of Commons if it has collected 100,000 signatures. However, the Backbench Business Committee can only consider an e-petition for debate if an MP makes a case for the subject to be debated. In October 2012, the Hansard Society published a review of the first year of e-petitions which showed that 14,092 had been accepted, with 3 million unique signatures. It is important to note, though, that UK e-petitions can easily be dismissed by Parliament. ${ }^{30}$

To optimize lawmaking activities by political activists and representatives of a lobby in the United Kingdom the crowd sourcing platform Jolitics.com was created. This resource copies the model of the work of the British Parliament, it provides for the stages of project introduction, its discussion and voting. Initially, the platform allows citizens to make proposals only in the field of national policy, but in the future it is planned to allow discussion of issues of local importance.

Users of Jolitics will be able to publish on the site a proposal (analogous to a bill) with a length of no more than 140 characters (similar to the entries in Twitter microblogging), as well as a brief description of the proposal. Other users can discuss the "legislative" initiative within four weeks, after which it is put to a vote. If the proposal is approved by more than 50 percent of the voters, it can be sent to a Member of Parliament with the number of voters who voted for it.

Up to the present time, Jolitics uses a closed registration system: in order to register, it is necessary to receive an invitation from a current participant or to register on the waiting list and receive an alert when the network becomes public. Participants who joined the network at an early stage are given the opportunity to transfer their voices to friends with similar political views, as well as to change their decision in voting.

Although this innovation is the introduction of a people's legislative initiative in a limited form - only in the form of a legislative proposal (there is no question of a draft law being drafted) - in this author's opinion, it does not yet achieve the concept of the people's legislative initiative in a purely legal sense.

The UK government is trying to make more information and data available to citizens through several initiatives. The Office of the Parliamentary Counsel (part of the Cabinet

30 Jamie Bartlett et al., Social Media Is Transforming How to View Society...: Vox Digitas (London: Demos, 2014). 
Office) has a Good Law Initiative which aims to make legislation more accessible online by providing simpler language and explanations. The Open Government Partnership UK National Action Plan 2013-2015 states that the government will promptly publish all new primary and secondary legislation on the website legislation.gov.uk, and make legislative data available in an open and accessible format to allow people to re-use content under the terms of the UK's Open Government Licence. Perhaps the most interesting of all is a website called data.gov.uk which hosts around 20,000 government datasets. Just over half of them are available as open data under the Open Government Licence, making $£ 80$ billion of government expenditures accessible to the public in detail. However, not all central government departments publish their spending data in a timely manner, in a consistent format or at the same level of richness, and some local authority spending data is missing completely. ${ }^{31}$

In Germany, an interesting platform transforming this traditional way of democratic participation into an e-democracy tool was established in 2005: the e-petition portal of the Bundestag (German parliament). ${ }^{32}$

Sending individual or public petitions to parliament is one of the fundamental rights to be found within the constitution, the German Basic Law. After registering on the website, citizens have the possibility to exercise this right online, making the procedure much more convenient. While the submission of individual non-public petitions relating to personal concerns becomes certainly more comfortable by means of the portal (one just has to fill in an online form), the platform is particularly interesting with respect to public petitions, which can be supported by other citizens. In this regard, instead of going through the exhaustive process of collecting signatures on paper, the petitioner just has to submit the petition on the e-petition platform and other registered users can "sign" it online with just a few clicks. All public petitions appear in the petition forum, which is the centerpiece of the website. Here, the users get an overview of all petitions and can also have a discussion on them.

Since all public petitions submitted are first screened with respect to compliance with several specific rules (e.g. they need to be of public interest and suitable for discussion), it may take some time for a petition to get published and be open for signature and discussion. If the parliamentary commission for petitions is of the opinion that a petition does not comply with the rules for publication, it may still be treated as an individual petition.

Even though the mere number of supporters gathered for a petition has no direct influence on its success in the subsequent parliamentary scrutiny procedure, a large number of supporters makes it of course much easier to be heard. In this respect, there is a quorum of 50,000 signatures that has to be reached within four weeks after

\footnotetext{
31 Bartlett et al. 2014.

32 E-petitions in Germany (Jan. 3, 2019), available at https://democracyoneday.com/2013/03/07/epetitions-in-germany/.
} 
the online publication of the petition (traditional paper signatures may be added, but not signatures collected via other non-official online platforms). Having reached this figure, the parliamentary commission for petitions usually holds a public debate on the issue, to which the petitioner is invited and has the possibility to present his or her arguments before the delegates.

Irrespective of whether a petition is an individual or a public petition and whether the quorum has been reached or not, all petitions complying with the general formal rules go through the parliamentary scrutiny procedure conducted by the parliamentary commission for petitions. At that time, the members of the commission debate the issue and request a statement from the respective responsible ministry, which is in turn scrutinized and taken into consideration. Once the commission has come to a decision, it presents a recommendation to the plenum of the Bundestag, which then decides on the issue. Usually this marks the end of the procedure, meaning that the petition is either rejected (e.g. because a change in legislation is not possible) or accepted. Either way, the petitioner receives an explanatory statement outlining the reasons for the decision, whereupon the statements concerning public petitions are published in the online forum. However, the fact that a petition is successful does of course not mean that legislation is now automatically changed according to the petitioner's wishes. Instead, the petition is usually submitted to the government, which might also be requested to take action regarding the issue concerned.

The usefulness and effectiveness of the overall German petition procedure or legislation notwithstanding, the e-petition system of the Bundestag is certainly a simple but very interesting means to modernize a traditional tool of democratic participation.

\section{The Modern Possibilities of Citizens' Electronic Initiatives in the Russian Federation}

In the Russian Federation until April 2013, the right of civil legislative initiative was not provided for at the federal level. Citizens could submit their own suggestions and projects only through the entitled bodies that have the right to initiate legislative initiative in accordance with Article 104 of the Constitution of the Russian Federation (the President of the Russian Federation, the Federal Council, Members of the Federal Council, Deputies of the State Duma, the Government of the Russian Federation, legislative bodies of the subjects of the Federation, as well as the Constitutional Court of the Russian Federation, the Supreme Court of the Russian Federation on their jurisdiction).

The need for this step was stressed by V. Putin in his article "Democracy and the Quality of Government" ${ }^{\prime 33}$ and in the annual message to the Federal Assembly.

33 Путин В.В. Демократия и качество государства // Коммерсант. 2012.6 февраля. № 20 [Vladimir V. Putin, Democracy and the Quality of Government, Kommersant, 6 February 2012, No. 20] (Jan. 3, 2019), also available at https://www.kommersant.ru/doc/1866753. 
He points out that it is necessary to be able to respond to the demands of society, which are becoming increasingly complicated, and in the conditions of the "information age" they acquire qualitatively new features. In this regard, he suggests implying a rule of mandatory consideration in the parliament of those public initiatives that will collect 100 thousand or more signatures on the Internet. Of course, for this, he emphasizes, it is necessary to develop an order for the official registration of those who want to become a part of such a system.

Nowadays, the Decree of the President of the Russian Federation of 4 March $2013^{34}$ provides the possibility for citizens to file their legislative proposals through the electronic resource "Russian Public Initiative."Yet it should be noted that citizens showed legislative activity even before introducing such mechanisms in the legal system: for example, the website podkontrol.ru, where an online petition was posted on the adoption of the law"On the Control of Foreign Financing of Non-Governmental Organizations." Within a few days, over 11,000 signatures were collected under the petition. The result of this initiative was the adoption of the relevant law by the State Duma of the Russian Federation. Obviously, the adoption of the relevant presidential decree was a necessary and timely measure.

According to that decree, public initiatives are proposals of citizens of the Russian Federation on issues of social and economic development of the country, state improvement and municipal management, directed with the use of the Internet resource "Russian Public Initiative" (hereinafter the Internet resource) and meeting the established requirements.

Before the initiative will be posted on the Internet, preliminary examination is required, which is carried out by the Information Democracy and Civil Society Development Foundation "Information Democracy Fund."The period of its holding should not exceed two months. At the same time, the presidential decree provides a number of criteria for the inadmissibility of public initiatives: the presence of obscene, offensive language; threats to life or health of citizens; and calls for extremist activities. In the same way, the initiative is considered for compliance with the constitution, the generally recognized principles and norms of international law, etc. The resolution of these questions may completely depend on the personal views of experts. In this case, the possibility to appeal the results of the examination is not provided for.

The rules provide for refusal to place a public initiative when a description of the problem is absent, there is a lack of options for its solution, or because of the unreasonableness of the proposed options. In this author's opinion, the refusal

34 Указ Президента РФ от 4 марта 2013 г. № 183 «О рассмотрении общественных инициатив, направленных гражданами Российской Федерации с использованием интернет-ресурса «Российская общественная инициатива»» [Decree of the President of the Russian Federation No. 183 of 4 March 2013. On Consideration of Public Initiatives Directed by Citizens of the Russian Federation Using the Internet Resource "Russian Public Initiative"] (Jan. 3, 2019), available at http://www.pravo.gov.ru. 
criteria are fixed too generally. There are no clear requirements for the validity of options for solving the existing problem, and also for their sufficiency.

The public initiative posted on the Internet resource should be supported in the course of voting using the Internet resource. The initiative is considered to be supported when, within one year after its posting on the Internet resource, it received:

1) no fewer than 100 thousand votes of citizens in support of the initiative at the federal level;

2) at least $5 \%$ of the votes of citizens permanently living in the territory of the relevant region of the Russian Federation (for regions of the Russian Federation with a population of more than 2 million people - no fewer than 100 thousand votes of citizens permanently living in the relevant region of the Russian Federation) in support of the initiative at the regional level;

3 ) at least $5 \%$ of the votes of citizens permanently living in the territory of the respective municipality, in support of the initiative at the municipal level.

At the same time, the number of opponents of the public initiative that is being discussed is not taken into account in any way, although the site provides for the possibility to vote against the proposed project. This problem is fundamental, since a democratic state, of course, is obliged to take into account the opinion of the minority in order to achieve full objectivity. After all, there may be a situation in which the number of votes in support of the initiative will be less than the number of votes against. However, there are no legal mechanisms for taking into account the opinion of the population in opposition to the project.

Therefore, if the number of those who voted against exceeds 51 percent of the required number of votes, one may suggest posting a survey questionnaire on the website to identify the reasons for disagreement.

It should be noted that the Decree of the President of the Russian Federation does not fix the procedure for the formation of expert groups; it does not even reflect whether representatives of the scientific community or experts in norm-setting are to be included. In addition, the decision-making process of the expert group is not transparent.

Summing up, one may note that the citizens' legislative initiative is one of the most important forms of public initiative, for a well-established mechanism of legislative initiative gives citizens the opportunity to directly exercise their power by creating the laws under which they live, which contributes to the development of civil society and the improvement of the legal system of the country. Therefore, it is very important to regulate the legislative initiative of citizens not only by presidential decree and certain laws of subjects of the Russian Federation, but to adopt a federal law that consolidates these social relations. 


\section{Conclusion}

Across Europe there is a very broad and sustained trend of citizens losing trust and confidence in the way politics is being done. According to a 2014 Ipsos MORI poll, just 16 percent of Britons trust politicians to tell the truth - a lower number than that given for trust estate agents or bankers. In Germany, 68 percent of the people distrust politicians, while 86 percent of the French share the same view. Despite a small upturn in the most recent poll, the latest Eurobarometer survey shows that just 32 percent of British adults trust parliament, while 28 percent of French citizens, 40 percent of Germans and only 24 percent of Italians trust their government. ${ }^{35}$

Exactly what is behind these trends is not entirely clear. Causation is hard to establish given all the other trends that are affecting trust, from revelations of corruption to the economic crisis of 2008 and its aftermath. But one way that people's digital experiences could be changing their attitudes towards politics is that they interpret the slowness of responses and inaccessibility of processes in that realm as a sign of aloofness, rather than the result of the old technology used in politics. The digital revolution has enabled people to speak their minds far more easily, get more involved in creating information, and interacting with each other.

The overwhelming majority of this sort of online activity is ignored by the political processes. Researchers and academics have long noted this disconnection with the technology of politics, which remains offline and "clunky" by comparison: voting once every few years, responding to consultation documents from time to time, writing to elected officials. For a while, speed looked to be the way to bridge the digital chasm, to make politics more like an e-commerce experience - quick, seamless and easy. Technophiles have also written about the possibility of returning to direct democracy where, thanks to digital technology and processing power, every citizen can vote directly on every single issue and policy. ${ }^{36}$

Others are more skeptical. Political scientist Gerry Stoker points out that most citizens do not care to engage in politics on a regular basis - so the last reform that would interest them is more participation. ${ }^{37}$ Indeed, Hansard research found that only 29 percent of British voters think that having more of a say (e.g. more referendums and more consultation) would bring about a significant improvement in the political system.

This author suggests that the answer lies in the quality of engagement, not just speed, ease or the quantity of opportunities. Quality is about how citizens are

35 Trust in Professions: Long-term trends, Ipsos MORI, 30 November 2017 (Jan. 3, 2019), available at https://www.ipsos-mori.com/researchpublications/researcharchive/15/Trust-in-Professions.aspx.

36 Jamie Bartlett \& Heather Grabbe, E-democracy in the EU: The Opportunities for Digital Politics to Re-engage Voters and the Risks of Disappointment (London: Demos, 2015).

37 Gerry Stoker, Building a New Politics (London: The British Academy, 2011). 
involved in the political process. It requires transparency not just in the amount of information put on websites, but that the data is searchable, shareable, discussed and acted upon. If voters feel that the systems and procedures that govern how decisions are taken are aloof, closed, incomprehensible and unaccountable, then they will not value the democratic processes, where their participation is vital. When we experience a better quality of engagement, where we can get involved personally, then we are more likely to trust the interlocutor.

The constitutional development of Russian statehood, aimed at approbation of new forms of public initiatives of citizens and the maintenance of classical institutions of direct democracy, objectively determines research in the field of legal regulation and implementation of public initiatives. As a result of reforms in public administration carried out in the Russian Federation, there is the emergence of modernized forms of public initiatives, especially electronic ones.

These innovations increase the degree of involvement of citizens of the Russian Federation in the public and political life of the country, contribute to increasing the activity of citizens with their participation in public initiatives and ultimately contribute to establishing a constructive dialogue between the authorities and society.

However, in the Russian Federation and in the European countries there are similar issues in the process of modernizing civil legislation initiatives:

1) The dispersion of the rules governing the procedure for considering civil initiatives, on various regulatory legal acts, which makes it difficult to implement such initiatives;

2) The low level of citizens' awareness of the existing forms and mechanisms for the realization of the citizens' right to public initiative;

3) The weak organization of civil society formal institutions. Obviously, the possibilities of associations of citizens with the status of public associations are higher than spontaneous or permanent informal groups formed according to interests or the principle of territorial residence. Public associations are organized, have experience, qualifications, resources, and can more actively and specifically put forward initiatives. But this possibility is not clearly realized by citizens.

Thus, the development of the electronic legislative initiative is a highly topical issue worthy of further research and open to comparative study in respect of the experiences in the Russian Federation and in Europe.

\section{Acknowledgments}

This article was written as part of the scientific research project MK-2440.2018.6 commissioned by the Grant Council of the President of the Russian Federation. 


\section{References}

Bartlett J. \& Grabbe H. E-democracy in the EU: The Opportunities for Digital Politics to Re-engage Voters and the Risks of Disappointment (London: Demos, 2015).

Bartlett J. et al. Social Media Is Transforming How to View Society...: Vox Digitas (London: Demos, 2014).

Lutz G. Switzerland: Citizens' Initiatives as a Measure to Control the Political Agenda in Citizens' Initiatives in Europe: Procedures and Consequences of Agenda-Setting by Citizens 17 (M. Setälä \& T. Schiller (eds.), London: Palgrave Macmillan, 2012).

Marczewska-Rytko M. Popular Initiative and Referendum in Switzerland (20002010), 9 Studies in Politics and Society 284 (2012).

Politics in the American States: A Comparative Analysis (V.H. Gray et al. (eds.), $9^{\text {th }}$ ed., Washington, D.C.: CQ Press, 2008).

Renard-Biancotto S. Le droit de pétition sous la cinquième République, 1 Revue de la recherche juridique, droit prospectif 223 (2000).

Stoker G. Building a New Politics (London: The British Academy, 2011).

\section{Information about the author}

Ksenia Ivanova (Tyumen, Russia) - Associate Professor, Department of Constitutional and Municipal Law, Tyumen State University (38 Lenina St., Tyumen, 625000, Russia; e-mail: k.a.ivanova@utmn.ru). 